\title{
Kina er stort - men ikke så stort som antaget
}

Frede Vestergaard

\section{Nye tal fra Verdensbanken viser, at Kinas samlede BNP i 2005 udgjorde en mindre del af den samle- de globale produktion end hidtil antaget. Men størrelsen er stadig imponerende}

Ved udgangen af 2007 var der 549 millioner mobiltelefon-abonnenter og 345 millioner fastnet-abonnenter i Kina. Antallet af mobiltelefonabonnenter steg med 76 millioner i løbet af året. Med en befolkning på nu 1.330 millioner mennesker, inklusive børn og gamle, siger tallene noget om, hvor hurtigt de økonomiske og samfundsmæssige ændringer foregår. Ifølge Boston Consulting Groups er der 310.000 dollarmillionærer (defineret som investeringsmulige aktiver) i Kina.

Den økonomiske revolution i Kina i december 1978 satte gang i en gradvis overgang fra planøkonomi til markeds $\varnothing$ konomi. To tredjedele af økonomien er nu markedsstyret, og det i en grad, der er langt mere udtalt end i fx Danmark.

Formelt regeres Kina af et teknokrati, der kalder sig kommunistisk, men der er tale om kommunisme med et kapitalistisk ansigt. Det kommer bl.a. til udtryk i, at den kraftige $ø$ konomiske vækst er ledsaget af en voksende ulighed. Overgangen til markedsøkonomi frigjorde kolossale kræfter trods det manglende demokrati.

Den økonomiske vækst har været fænomenalt stor, og det samme gælder den kinesiske udenrigshandel. Eksporten er vokset fra 14 milliarder dollars i 1979 til 762 milliarder i 2005, mens importen i samme periode steg fra 16 milliarder dollars til 660 milliarder dollars. I 2004 overhalede Kina Japan som landet med den tredjestørste udenrigshandel efter USA og Tyskland.

Den dramatiske vækst i den kinesiske eksport, og dermed i den kinesiske økonomi afspejler den kinesiske udviklingsmodel. Den er og har i 
årevis været baseret på en stærkt undervurderet valutakurs, som i kombination med et lavt lønniveau har gjort arbejdskraftintensiv produktion særdeles konkurrencedygtig og dermed skabt millioner af arbejdspladser uden for landbruget.

Arbejdskrævende produktion er dyr i industrilandene, og mange traditionelt vellønnede arbejdspladser i Europa og Nordamerika er af samme grund flyttet til Kina (eller Indien og andre lavtlønslande) eller er blevet udkonkurreret af produkter fra Kina og andre udviklingslande.

Modstykket til eksporten af arbejdskraftintensive varer til Vesten har været en stærk vækst i Kinas import af maskiner m.m. og råstoffer, herunder energi. Udviklingen i udenrigshandelen har bevirket at Kinas andel af verdensøkonomien har været stærkt stigende i de seneste $10-15$ år.

\section{Hvor stort er Kina?}

Den økonomiske vækst $\mathrm{i}$ Kina lå $\mathrm{i}$ årene fra 1996-2006 i gennemsnit på 8,3 procent (2007: 11,7 procent), hvilket er en markant højere vækst end noget andet større land. Til sammenligning lå den tilsvarende gennemsnitsvækst i de øvrige BRIK-lande, Brasilien, Rusland og Indien, på hhv. 1,1, 5,4 og 5,7 procent. Væksten i OECD's medlemslande - industrilandene - var i samme ti-årige periode 2,04 procent i årligt gennemsnit. Altså en fjerdedel af den kinesiske.
I de senere år er der derfor opstået spekulationer om, hvornår Kina vil overhale USA som verdens største økonomi. Det amerikanske Government Accountability Office, der hører under den amerikanske kongres, vurderede således sidste år, at Kinas økonomi målt i købekraftpariteter - såkaldte PPP-dollars - ville overhale USA så tidligt som i 2012.

Denne spådom var dog for tidligt ude. Den kinesiske økonomi er 40 procent mindre end tidligere antaget. Det fremgik tidligere i år af nye beregninger fra Verdensbanken. Her offentliggjorde man i januar nye beregninger af 146 landes bruttonationalprodukt og bruttonationalprodukt pr. indbygger på grundlag af de første opdaterede købekraftspariteter siden 1993.

Tallene viser, at Kinas samlede bruttonationalprodukt i 2005 ikke udgjorde 14,2 procent af den samlede globale produktion men - kun 9,7 procent. Indiens andel blev tilsvarende justeret ned fra 6,2 til 4,3 procent. Tallene betyder naturligvis ikke, at Kinas og Indiens økonomier er mindre, end de hele tiden har været. Kun at deres relative størrelse er betydeligt mindre end tidligere antaget.

Det hører også med til billedet, at trods nedjusteringen har Kina passeret såvel Tyskland som Japan, og har dermed den næststørste økonomi i verden, når sammenligningen baseres på købekraftkorrigede BNP-tal.

Nedjusteringen har naturligvis 
også konsekvenser for størrelsen af bruttonationalproduktet pr. indbygger. De omtalte beregninger viser, at bruttonationalproduktet pr. indbygger ikke var 6.760 PPP-dollars i 2005, men 4.091 PPP-dollars, hvilket vil sige en tiendedel af det amerikanske niveau og lidt mere end en syvendedel af OECD-landenes PPPdollar-gennemsnit. Indiens opdaterede PPP-indkomst opgøres til 2.126 dollars, hvad der giver cirka samme forhold mellem Kina og Indien - 2:1 - som beregnet efter de gamle PPPkurser.

Opgjort efter almindelige markeds-kurser udgjorde det kinesiske bruttonationalprodukt 5,0 procent i 2005 (og Indiens 1,8 procent) af den samlede globale produktion, mens USA's andel var 28 procent.

Efter de nye PPP-kurser er USA's andel 22,5 procent mod 20,5 i følge de gamle kurser, hvor Kina efter de gamle kurser som tidligere nævnt lå på 14,2 procent. Det var denne svindende forskel, der udløste spørgsmålet om, hvornår Kinas totale økonomi (med godt 1.300 millioner indbyggere) vil overhale USA's (med 300 millioner indbyggere).

Den såkaldte Vækstkommission (Commission on Growth and Development), der offentliggjorde en stor analyse af den økonomiske vækst og udvikling i de 13 hurtigst voksende udviklings- og transitionslande i slutningen af maj, har foretaget en beregning af, hvor mange år det vil vare, før disse lande indhenter
OECD-landene, regnet i købekraftkorrigeret bruttonationalprodukt pr. indbygger.

For Kinas vedkommende lød tallet på 23 år (og for Indien 50 år) forudsat, at såvel Kina (og Indien) som OECD-landene vokser med den maksimale vækstrate, som de har haft i tiåret 1996-2006, hvilket for Kina var 10,1 procent, (for Indien 7,7 procent) og for OECD-landene 3,08 procent.

Disse beregninger er foretaget på grundlag af de gamle PPP-kurser. Selv om Vækstkommissionen har arbejdet i tilknytning til Verdensbanken, er rapportens tal desværre ikke opdateret med de nye PPP-tal. Men eftersom de nye PPP-beregninger viser, at Kinas økonomi er cirka 40 procent mindre end hidtil antaget, ville en nyberegning af catch-upperioden vise en hel del år ekstra.

Formålet med at opgøre indkomst og produktion i købekraftkorrigeret valuta (PPP-dollars) er at korrigere for de forskelle, der skyldes forskelligt prisniveau. Mens forskelle i prisniveau er relativt små mellem industrilandene indbyrdes, er der store forskelle mellem i-lande og ulande.

Et frisørbesøg der i Danmark koster eksempelvis 150 kroner, koster i Kina et langt mindre beløb, måske mindre end 5 kroner uden for de gader, hvor turister bevæger sig. For en dansker, der kommer til Kina med penge tjent i Danmark er det 30 gange billigere end i Danmark. Men ydelsen er i princippet den 
samme. Skal man sammenligne levestandarden i to lande, er det derfor nødvendigt at korrigere for disse prisforskelle, når man sammenligner indkomst og produktion. Det kan give problemer med hensyn til forskelle i den oplevede kvalitet af de varer og tjenester, som sammenlignes, men problematikken er reel. Det internationale købekraftsberegningsprojekt fandt, at prisniveauet $\mathrm{i}$ Kina lå på omkring 42 procent af det amerikanske.

Det er første gang siden begyndelsen af 1980'erne, at Verdensbanken har justeret sine PPP-tal, som omfatter 146 lande. De nyberegnede BNPtal betyder ikke, at den økonomiske vækst i Kina har været mindre end tidligere antaget, understreger Verdensbanken, men derimod at væksten startede fra et lavere niveau end tidligere antaget.

\section{Behovet for ressourcer}

Modstykket til Kinas store andel af den globale produktion - og dets store eksport - er en hastigt voksende andel af det samlede globale ressourceforbrug. Eksempelvis voksede Kinas andel af den samlede stålproduktion i verden fra 12-13 procent i 1996 til 33-34 procent i 2006. Kinas andel af den globale cementproduktion var ifølge det nederlandske miljøvurderingsinstitut Planbureau voor de Leefomgeving i overkanten af 50 procent.

Målt ved værditilvæksten tegnede den kinesiske industriproduktion sig i 2006 for 11-12 procent af den globale industriproduktion, og den runder formentlig 15 procent $i$ år. Det skal sammenlignes med en andel på tre procent i 1990. Væksten har ganske enkelt været fænomenal. Størst er Kinas andel af den globale produktion inden for computere og kontorudstyr, nemlig 42 procent i 2007, hvorefter kommer tekstiler og tøj med 27-28 procent.

En anden vigtig ressource for den $\varnothing$ konomiske udvikling er energiforsyningen. Kinas energiforbrug har været stærkt stigende som følge af den stærke produktionsvækst. Alene i 2007 var stigningen i det primære energiforbrug på 8 procent. Kul udgør aktuelt 69 procent af det samlede energiforbrug og vil fortsat udgøre en overvejende del af energiforbruget i lang tid fremover.

Kina har meget store kulreserver. Men i takt med det stærkt stigende antal biler og den voksende flytrafik vokser også efterspørgslen efter olie. Siden 1993 har Kina været nettoimportør af olie, og importen har været hastigt stigende. Det kinesiske olieforbrug fordobledes fra 1994 til $2003 \mathrm{og}$ ventes at være fordoblet igen i 2010.

Kina og andre asiatiske lande meldes i år at stå for en stor del af væksten i den globale efterspørgsel efter olie, cirka 70 procent af dette års efterspørgselsvækst på ca. 1 million tønder pr. dag. Resten af efterspørgselsstigningen kommer fra Mellem- 
østen og Latinamerika. For mens olieefterspørgslen er faldet i både USA og Europa på grund af fordoblingen af den internationale markedspris på olie i løbet af det sidste år, er efterspørgslen efter olie fortsat steget i en række udviklingslande, bl.a. nogle af de største som Kina, Indien og Indonesien, fordi disse lande holder benzin- og dieselpriserne nede ved tilskud fra statskassen. I 2007 var Kina ansvarlig for 52 procent af dette års stigning i det globale energiforbrug.

Ifølge den Hongkongbaserede HSBC-bank vil Kina med de nuværende regler og en fortsat verdensmarkedspris på 120 dollars pr. tønde i 2008 komme til at bruge fire procent af statsbudgettet på brændstofsubsidier, svarende til 27 milliarder dollars med mindre subsidierne mindskes, hvilket næppe sker i år på grund af den i forvejen høje inflation. Det internationale energiagentur, IEA, forudser, at Kina i 2010 vil være verdens største forbruger af energi. Og bliver det ikke i 2010, bliver det ganske få år senere.

Kina er allerede verdens næststørste marked for motorkøretøjer og verdens tredje største producent, og der er et stort potentiale for efterspørgsel efter biler. For tiden er der blot 11 biler pr. 1.000 indbyggere i Kina mod 480 i USA (og 377 i Danmark). Produktionen af biler voksede fra 7,2 millioner i 2006 til 9,04 millioner i 2007, og den hurtige vækst i bilproduktionen vil fort- sætte i de kommende år i takt med at nye, store vestlige investeringer $i$ joint-venture fabrikker bliver udmøntet. Produktionen af personbiler udgjorde 4,95 millioner i 2007 $\bmod$ 1,09 millioner i 2002.

Det stigende forbrug af olie og andre råstoffer har fået Kina til at søge samarbejde med lande i Afrika og Latinamerika. Senest indgik Kina i maj en omfattende, flerårig aftale med Congo-Kinshasa til en værdi af 9,25 milliarder dollars. I henhold til aftalen skal Congo levere 10,2 millioner tons kobber og 620.000 tons kobolt til Kina til gengæld for hundreder af sundhedsklinikker, hospitaler og skoler, to store vandkraftanlæg samt bl.a. 3.000 kilometer jernbanespor og 3.300 kilometer asfalterede veje.

\section{Stærkt stigende elforbrug}

Ikke blot olieforbruget stiger. Det gælder også elforbruget. Regnet pr. indbygger steg elforbruget (inklusive industriens store forbrug) fra 719 kilowatt-timer i 1993 til 1.684 kilowatt-timer i 2004, hvilket præcist svarede til en fjerdedel af det danske elforbrug pr. indbygger samme år (og tre gange det indiske).

Forudsætningen for den kraftige vækst i elforbruget har været et omfattende byggeri af kulfyrede kraftværker. Alene i årene 2006 og 2007 er elproduktionskapaciteten samlet set vokset med ca. 200.000 MW, selv om en del mindre, og mindre effek- 
tive, værker er taget ud af drift. Stigningen over de to år svarer til tyve gange den eksisterende el-kapacitet i Danmark eller tre gange Storbritanniens. Ved udgangen af 2007 angives produktionskapaciteten at have været $145.000 \mathrm{MW}$ vandkraft, 554.000 MW fossilt baserede kraftværker, $9.000 \mathrm{MW}$ kernekraft og 4.000 MW vind, i alt 712.000 MW.

Den helt overvejende del af elproduktionen sker på basis af kul, men hvor kraftværkerne i overvejende grad befinder sig i sydøst, graves kullene op i nord og nordvest. Det betyder meget lange transporter, som belaster jernbanenettet kraftigt. Det er derfor i de områder, der ligger langt fra kulreserverne, at nye kernekraftværker skal bygges. China Electricity Council opstillede i juni 2008 et mål på 60.000 MW kernekraft i 2020.

Ud over at lægge pres på transportsystemet betyder det store forbrug af kul udledning af store mængder svævestøv og drivhusgasser. Kina overhalede i 2006 USA som den største udleder af drivhusgasser. Ifølge det nederlandske miljøvurderingsinstitut stod Kina i 2007 for 24 procent af den globale udledning af kuldioxid fra fossile brændsler og cementproduktion m.m., mens USA's andel var 21 procent og EU15's andel 12 procent.

Det store kinesiske udslip skyldes blandt andet den store cementproduktion, der i 2007 stod for en femtedel af det samlede udslip af kuldi- oxid. Det nylige jordskælv bevirker, at der også $i$ år og næste år vil blive produceret ekstra meget cement til genopbygning af de cirka en million boliger, der blev ødelagt.

Også i de kommende år vil kul spille den afgørende rolle i elproduktionen, men kernekraft, der i dag tegner sig for to procent af energiforsyningen, vil få en større rolle. Et af flere måltal, der har været nævnt af forskellige instanser, lyder på en kernekraftandel på fem procent i 2020. Ud over de eksisterende 11 kernekraftværker er seks under bygning, og adskilligt flere er på vej ind i byggefasen. Ligeledes er forskellige vandkraftværker under bygning, ligesom alternativ energi som vindmøller og biobrændsel er under udvikling.

\section{Faldende fattigdomsrate}

De sidste tredive års hurtige økonomiske vækst har trukket mange hundrede millioner mennesker ud af $\mathrm{u}$ landsfattigdommen. De snart 600 millioner mobiltelefonabonnenter er blot et enkelt eksempel på, at hundreder af millioner kinesere har råd til mere end de basale fornødenheder. Øget velstand og stigende urbanisering øger også efterspørgslen efter andre fødevarer end de mest basale, herunder animalske produkter, der nødvendiggør en vis import fra udlandet af korn, soja og andre foderstoffer.

Men der er også kommet en sti- 
gende ulighed, bl.a. som konsekvens af, at det sundhedssystem og de sociale ordninger, der var tilknyttet de gamle statsejede virksomheder, $i$ vidt omgang er gået i opløsning uden at være afløst af noget andet.

Nedjusteringen af størrelsen af Kinas økonomi som konsekvens af de nye købekraftpariteter ændrer imidlertid ikke ved, at Kina har haft den største og hurtigste nedgang i fattigdomsraten nogensinde. Hvad de derimod viser er, at Kina - og kineserne - for tredive år siden var fattigere end hidtil antaget.

Verdensbankens gamle PPP-mål havde som resultat, at ca. 64 procent af befolkningen i 1981 havde et forbrug på mindre end en dollar om dagen. Et tal, der var faldet til 10 procent i 2004. Det samme fattigdomsmål - en dollar om dagen - giver med de nye PPP-tal en fattigdomsrate på 74 procent i 1981 faldende til 15 procent i 2004. Målt ved en-dollar-om-dagen-kriteriet var og er der altså flere fattige end tidligere antaget.

Verdensbanken har i lavet en ny beregning baseret på et basic-needskriterium, som baserer sig på, hvor meget en familie behøver for at kunne konsumere 2100 kalorier pr. dag plus andre basale fornødenheder. Ifølge denne beregning er fattigdomsraten faldet fra 64 procent i 1981 over 33 procent i 1990 til 10 procent i 2004 og syv procent i 2007.

Den faldende fattigdomsrate skyldes ikke kun den økonomiske udvik- ling, men også den demografiske forskydning af befolkningens aldersstruktur. Uden etbarns-politikken ville folketallet alt andet lige have været 300-400 millioner højere end de 1.330 millioner, det faktisk er. Til gengæld har Kina fået en aldersstruktur, hvor de ældre årgange er meget større end de unge, hvad der vil lægge en stor byrde på de erhvervsaktive i de kommende år.

Tilmed er kønsfordelingen skæv. Forholdet mellem nyfødte drenge og piger var 108:100 i 1981, stigende til 112:100 ved den fjerde folketælling i 1990 og ved den seneste folketælling i 2002 var forholdet 117:100.

\section{Valutareserverne}

En status over Kinas aktuelle økonomiske udvikling må også berøre Kinas voldsomt store valutareserver. De er tidoblet siden 2000 og er nu på 1.700 milliarder dollars, en konsekvens af at eksporten i en årrække har været væsentligt større end importen, bl.a. som følge af en undervurderet valutakurs.

De store valutareserver vil bl.a. give Kina mulighed for store udenlandske investeringer i fremtiden, såsom at købe sig ind i store virksomheder i USA og Europa, og foretage direkte investeringer i Afrika og andre steder i verden.

Frede Vestergaard er cand. oecon. og journalist. 